\title{
CURRENT STATUS, STANDARDIZATION- AND CERTIFICATION-RELATED REGULATORY CHALLENGES FACING UKRAINE WITH ITS EU PARTNERSHIP AGENDA
}

\author{
Maryna Derevyanko" \\ Olena Terekh** \\ Mykola Lazarenko*** \\ Anna Bolotina*** \\ Vitaliy Zelensky ${ }^{* * * * *}$
}

\begin{abstract}
This study assesses the existing initiatives of the Ukrainian government in the field of regulation of standardization and certification, related to the implementation of the EU-Ukraine Association Agreement, and the adaptation of Ukrainian legislation to European standards. The study intends to identify the challenges that may create barriers for Ukrainian businesses in this area and to determine the areas and prospects of the politically motivated regulation related to their overcoming. Considering the evolution of regulation in the relevant area in Ukraine, the study gives grounds to assert that in recent years the government has made significant efforts in adapting national standards of a technical regulation to the EU legislation, which are related to simplification of standardization and certification procedures and access to both EU and Ukrainian markets. In practical terms, this study is of interest not only to lawyers but also for all businesses focusing both on European and Ukrainian markets.
\end{abstract}

KEYWORDS: Agreement on Conformity Assessment and Acceptability of Industrial Products, non-tariff barriers, reforms

\footnotetext{
Maryna Derevyanko, Taras Shevchenko National University of Kyiv, Kyiv, Ukraine; derevyanko.maryna@rambler.ru.

** Harold Neal, University of New York in Prague, Prague, Czech Republic; hneal@unyp.cz. **** Mykola Lazarenko, Taras Shevchenko National University of Kyiv, Kyiv, Ukraine.

***** Anna Bolotina, Sumy National Agrarian University, Sumy, Ukraine; dihtiar.anna@ukr.net. ******Vitaliy Zelensky, Taras Shevchenko National University of Kyiv, Kyiv, Ukraine; ze.vit@ yandex.ua.
} 


\section{INTRODUCTION}

The political and economic goals of the EU-Ukraine Association Agreement, which are fundamental for the future of Ukraine as an independent and stable European state, have been fully defined and accepted by the Ukrainian society, as evidenced by the unchanged political vector. Its political component implies a deeper implementation of the country's European Choice, which means the introduction of fundamental European values, particularly democracy, the rule of law, respect for human rights, and standards of the European security system. Although the Agreement does not provide for EU membership, such a possibility is not ruled out in the long term. The economic goal, in this case, is to assist with the development of the Ukrainian economy through increased trade with the EU and other countries and to help to reform the economy in line with European best practices. With an improved business climate, Ukraine will become attractive to foreign and domestic investors in export industries targeting the EU and other markets.

The Agreement regulates the development of Ukraine's economy by bringing standards and regulations in line with EU standards, which generally conform to international best practices. Harmonization of European and other standards is a much more important process than meeting purely technical requirements, and it underpins the implementation of good governance without corruption. In April 2014, the EU opened (almost completely) its market to duty-free imports from Ukraine. Transition periods apply to several products. This means opening additional export opportunities for the Ukrainian economy. Gradually, over several years, starting from January 2016, Ukraine has been eliminating import tariffs for EU countries. ${ }^{2}$

Proceeding from the logic of integration and the provisions of the EU-Ukraine Association Agreement, bringing the Ukrainian products in line with the requirements of European directives, under which the relevant technical regulations were adopted, is mandatory. This process also includes signing by Ukraine of the Agreement on Conformity Assessment and Acceptability of Industrial Products (ACAA), which is designed to ensure that Ukrainian products are recognized around the world and to eliminate certification costs for Ukrainian manufacturers in foreign markets. Optional application of the standards also meets the Technical Barriers to Trade Agreement requirements of the World Trade Organization (WTO).

Van der Loo, G.: The EU-Ukraine Association Agreement and Deep and Comprehensive Free Trade Area: a new legal instrument for EU integration without membership, Brill, 2016.

2 WTO: 'Trade policy review - Report by the Secretariat - Ukraine', 2016. [https://www. wto.org/english/tratop_e/tpr_e/s334_e.pdf] accessed on 15/06/2021. 
It should be mentioned that over the past 5 years Ukraine has made significant steps towards reforming the technical regulation system. In particular, in 2015, the Law of Ukraine "On Standardization" came into force, according to which the National Standards Body was established, and many obsolete state standards were abolished. Two levels of standardization were introduced - the national standards adopted by the national standards body, as well as standards and technical specifications introduced by companies. ${ }^{3}$

As many Ukrainian industrial companies are not integrated into global value chains, they found themselves outside of global processes. Expectations of a quick reorientation to the EU markets due to the establishment of a free trade area were not justified because of existing technical barriers. The free trade area between Ukraine and the EU has been in place since 2016, but one of its main components, ACAA, which has not yet been concluded, is currently not working. ACAA provides for the harmonization of technical regulations, standards, and conformity assessment procedures of the member states with the EU legislation in certain areas, followed by mutual recognition of conformity assessments and test results. ${ }^{4}$

Accordingly, technical barriers in the free trade area with the EU do not apply to raw materials and semi-finished products, but they currently exist for technological manufactured goods. The elimination of many standards and the regulation of the transition period have contributed to a specific situation in Ukraine where the entire certification or conformity assessment system actually profits from imports. The inconsistency of this situation comes from the duplication of procedures regarding compliance with technical regulations. ${ }^{5}$

Recent studies on the current status and challenges facing Ukraine in the field of regulation of standardization and certification, related to the adaptation of Ukrainian legislation to EU legislation and EU policy in this area, focus, in particular, on such issues as:

- analysis of the main changes in the national system of technical regulation; ${ }^{6}$

\footnotetext{
3 Eurointegration portal: 'An effective standardization system is high-quality and safe products', 2018. [http://eu-ua.org/analityka/efektyvna-systema-standartyzaciyi-yakisna-ta-bezpechna-produkciya] accessed on 15/06/2021.

4 Mission of Ukraine to the European Union, Access of Ukrainian goods to the EU market. ACAA Agreement, 2020. [https://ukraine-eu.mfa.gov.ua/en/2633-relations/torgovelno-ekonomichne-spivrobitnictvo-ukrayina-yes/dostup-ukrayinskih-tovariv-do-rinku-yes-ugoda-asaa] accessed on 15/06/2021.

5 Mirus, O.: 'When will there be "visa-free" in the EU for Ukrainian technological products', 2019. [https://www.epravda.com.ua/columns/2019/10/31/652964/] accessed on 15/06/2021.

6 Garasim, Y.J.: Analysis of the national system of standardization and certification in the context of the Association Agreement between Ukraine and the EU, Foreign Trade: Economics, Finance, Law, 3 2015, pp. 58-65.
} 
- harmonization of economic and legal arrangements to deepen relations between the EU and Ukraine; 7

- standardization of Ukrainian products when entering the European market; ${ }^{8}$

- EU-Ukraine Association Agreement and Deep and Comprehensive Free Trade Area ${ }^{9}$

- EU assistance and development programs for Ukraine and related issues of overcoming barriers for Ukrainian goods when entering the European market; ${ }^{10}$

- international harmonization of EU standards, taking into account the impact of imports and exports in developed and developing markets; ${ }^{11}$

- non-tariff protectionism in the EU countries and Ukraine. ${ }^{12}$

A review of existing studies suggests that assessment of the current state of regulation in the field of standardization and certification in Ukraine has been researched rather poorly in the light of the implementation of the Association Agreement, while the challenges facing the existing Ukrainian legal system in this field practically have not been considered at all. This factor, in turn, makes this study relevant.

The purpose of this study is to analyze and assess the current initiatives of the Ukrainian government in the field of regulation of standardization and

\footnotetext{
7 Predmestnikov, O., Gumenyuk, V.: Harmonization of economic and legal mechanisms for deepening EU-Ukrainian relations, Baltic Journal of Economic Studies, 5(1) 2019, pp. 174-181. [https://doi.org/10.30525/2256-0742/2019-5-1-174-181]

8 Romanova, T.V., Voloshina, O.A., Gavrilenko, O.O.: Standardization of Ukrainian products when brought to the European market, 2015. [http://global-national.in.ua/archive/8-2015/127. pdf] accessed on 15/06/2021.

9 Van der Loo, G.: The EU-Ukraine Association Agreement and Deep and Comprehensive Free Trade Area: a new legal instrument for EU integration without membership, Brill, 2016.

10 Miskimmon, A., O'Loughlin, B.: An EU recovery programme for Ukraine? Towards a new narrative for EU-Ukraine relations?, Cognition, Communication, Discourse, 172018 , pp. 75-91. [https://doi.org/10.26565/2218-2926-2018-17-05]; Daehnhardt, P.: German foreign policy, the Ukraine crisis and the Euro-Atlantic order: Assessing the dynamics of change, German Politics 27(4) 2018, pp. 516-538. [https://doi.org/10.1080/09644008.2018.1448386]; Wolczuk, K., Žeruolis, D.: Rebuilding Ukraine: An assessment of EU assistance, Ukraine Forum, 402018.

11 Curzi, D., Luarasi, M., Raimondi, V., Olper, A. : The (lack of) international harmonization of EU standards: import and export effects in developed versus developing countries, Applied Economics Letters, 25(21) 2018, pp. 1552-1556. [https://doi.org/10.1080/13504851.2018.1430327].

12 Melnyk, T.M., Pugachevska, K.S.: Non-tariff Protectionism in EU Countries and Ukraine, Business Inform, 1 2014, pp. 20-27.
} 
certification related to the implementation of the EU-Ukraine Association Agreement. In view of the analysis of the EU's respective regulation of the socio-legal relations under consideration, the study's aim is to identify the challenges that may create obstacles for Ukrainian businesses in standardization and certification and, on this basis, to determine the area and prospects of the politically motivated regulation related to their overcoming.

\section{MATERIALS AND METHODS}

The study is based on the analysis of legislative acts of Ukraine (Law of Ukraine "On Standardization", Law of Ukraine "On Amending Certain Legislative Acts of Ukraine to Reduce Pressure on Businesses by Market Surveillance Bodies"). The study also considers the following international documents and EU legislative acts in the area of regulation of standardization and certification:

- the EU-Ukraine Association Agreement.

- Directive 2001/95/EC on general product safety.

- Directive 85/374/EEC on the manufacturers' responsibility for the product quality.

- Regulation (EU) No. 1025/2012 of the European Parliament and of the Council of as October 25, 2012, concerning European standardization.

Using the method of political and legal analysis, the study examines the evolution of regulation of standardization and certification in Ukraine, taking into account the relevant regulation in the EU and context of adaptation of the Ukrainian legislation to the European requirements, related to the ratification of the EU-Ukraine Association Agreement. The study identifies the challenges that can pose barriers for Ukrainian businesses in this area of regulation. In addition, the study identifies areas and prospects of politically motivated regulation related to overcoming such challenges.

\section{RESULTS}

A key feature of standardization as an activity for the development and application of standards and regulations to ensure the safety of products, works and services are that its scope, application, and development level are almost unlimited. This, in turn, is due to the understanding of the fact that there is no area of human activity that does not come, in one way or another, into contact with standards, standardization and does not require application thereof. For- 
mal standardization always ends with the issuance of standards, benchmarks, or other regulatory and technical documents with formal certainty, the procedure of approval and characteristics, the degree of commitment, validity periods, etc. ${ }^{13}$ Standardization-related issues have become particularly important for Ukraine in recent years in the foreign trade context. Ukraine's European integration, as one of the first and main steps, involves the creation of the free trade area, which, in addition to the elimination of tariff barriers, primarily duties, requires the harmonization of technical requirements for products. For this reason, the Roadmap for Legislative Implementation of the Association Agreement included the standards to improve regulations, improvement of capabilities in metrology, standardization, market surveillance, certification, and accreditation, which have been regulated by the government for a long time.

Unlike Ukraine, standardization in the EU member states is implemented by private entities, and the market for product certification services is competitive in accordance with international standards. All stakeholders are involved in the development of standards, which are optional for the most part, while the government imposes only the basic mandatory safety parameters. CEN (European Committee for Standardization) and CENELEC (European Committee for Electrotechnical Standardization) are developing standards to meet these requirements. European manufacturers have the right to operate according to their own standards and be responsible for the safety of their products. ${ }^{14}$

As noted above, in Ukraine standardization has been exclusively the responsibility of state authorities for a long time. Since the collapse of the Soviet Union, technical specifications and standards have hardly been updated for many years. As a consequence, in practical terms, businesses not only repeatedly faced overregulation that created barriers to the national economy but also had to deal with non-recognition and distrust in respect of Ukrainian products in the European and global markets. ${ }^{15}$

The main difference between the national and international standardization and certification procedures was that in Ukraine standardization and certification were mandatory for almost all products, while in EU countries there are two categories of technical requirements for product types, not for specific products. The first category includes the recommended requirements that con-

13 Romanova, T.V., Voloshina, O.A., Gavrilenko, O.O.: Standardization of Ukrainian products when brought to the European market, 2015. [http://global-national.in.ua/archive/8-2015/127. pdf] accessed on 15/06/2021.

14 Cormenier, T., Patra, M., Garnier, C.: European CEN-CENELEC standardization on material efficiency for longer lifespan within circular economy, ELTEE 2018 2018, pp. 1-10.

15 Wolczuk, K., Žeruolis, D.: Rebuilding Ukraine: An assessment of EU assistance, Ukraine Forum, 402018. 
firm compliance with mandatory ACAA directives; other standard parameters such as service, quality, reliability, and durability are purely optional. ${ }^{16}$

By signing the Association Agreement with the EU, Ukraine committed itself to eliminate mandatory certification and switch to the European model of product conformity assessment. The new model is designed to reduce the burden on businesses. In most cases, manufacturers or importers are the ones declaring the quality and safety of their products. Only products with high potential risks (e.g., sterile medical devices) require mandatory certification. Under the Association Agreement, Ukraine committed itself to approve technical regulations (standards) for 27 categories of goods, of which 25 have already been approved.$^{17}$ Formally, the absence of technical regulations is not an obstacle to the manufacturing and sale of goods, but in fact, the minimum requirements for product safety are used by a bona fide manufacturer to protect at least its reputation.

Distributors also want quality and safe products. Although the state no longer requires certification or evaluation, distributors are asked to document the safety and quality of the products they offer for sale. Unlike the old model of state certification, the analogs of which exist only in the post-Soviet countries, the system of new technical regulations is clear and understandable to manufacturers all over the world. EU manufacturers benefited from legislative changes, as now they do not have to go through the conformity assessment procedures in Ukraine. Recognition of European manufacturers' certificates is sufficient for some product categories, while the declaration of quality and labeling following the technical regulations is sufficient for other product categories. $^{18}$

European standardization is a synthesis of common principles that are used worldwide to develop standards in a particular area. These principles were defined at the time when the orderly standardization was being established, and they are still in effect, basically in their original version. The EU standardization policy is designed to implement the following objectives: mutual conformity of national standards in the EU Member States; uniform adoption by EU member states of international standards and regulation of the procedure for their adoption; development of unified European standards in the

16 Cormenier, T., Patra, M., Garnier, C. : European CEN-CENELEC standardization on material efficiency for longer lifespan within circular economy, ELTEE 2018 2018, pp. 1-10.

17 Rodichkina, A.: Divorce with GOST: how Ukraine is implementing a new model of standardization, 2020. [https://www.epravda.com.ua/projects/regulation/5faa7f53e88e6/] accessed on $15 / 06 / 2021$.

18 Ibid. 
areas not covered by international standards. The European Union assigns regulatory responsibilities in standardization matters to the relevant European standardization bodies: the European Committee for Standardization and the European Committee for Electrotechnical Standardization. According to Belgian and French legislation, European standardization bodies have the status of non-governmental, non-profit organizations, and they are not institutions of the European Union. ${ }^{19}$ When dealing with standardization issues, the member states are represented by authorized delegates - one representative from each country. It should be mentioned that the EU market operates predominantly based on European standards. At the same time, when developing European standards, international standards are usually taken as a basis. ${ }^{20}$

The European Committee for Standardization - CEN (previously, until 1970, known as the European Committee for the Coordination of Standards) has existed since 1961. In 1970, the CEN Statutes were revised with the introduction, along with certain changes, of the mandatory development of European standards. National standards bodies of the following 17 European countries are CEN members: Austria, Belgium, Denmark, Finland, France, Germany, Greece, Great Britain, Iceland, Italy, Luxembourg, Norway, Netherlands, Portugal, Spain, Sweden, Switzerland Only EU and European Free Trade Association member states can be CEN members. CEN member states assign the leading role to international standardization within ISO (International Organization for Standardization) and IEC (International Electrotechnical Commission). It should be mentioned, however, that CEN's activities are largely based on the results achieved at ISO.

In addition to standards themselves, the European Committee for Standardization considers and adopts harmonization documents and preliminary standards. Harmonization documents are intended to remove technical barriers to trade between the EU states. Unlike standards, their objective is to identify existing instruments and regulatory arrangements that impede the development of trade relations. Such documents also imply a different procedure for their implementation by members of the standardization committee. Their main purpose is to ensure unified approaches to the application of international standards in the European Union. As for preliminary standards, it should be mentioned that they are developed in cases where harmonization procedures for the adoption of standards require a long period, regulation faces rapidly

19 Schepel, H., Falke, J.: Legal aspects of standardisation in the Member States of the EC and EFTA (Vol. 1), Office for official publications of the European communities, 2000.

20 Romanova, T.V., Voloshina, O.A., Gavrilenko, O.O.: Standardization of Ukrainian products when brought to the European market, 2015. [http://global-national.in.ua/archive/8-2015/127. pdf] accessed on 15/06/2021. 
changing technologies, in particular in an environment of rapid innovations. The validity of such standards is limited to three years. ${ }^{21}$

The administrative tasks are handled by the Central Secretariat (located in the capital of Belgium), which is a non-profit research organization under local laws. The European Committee for Electrotechnical Standardization was established in 1972. This organization consists of the national electrotechnical committees of the EU countries. The General Assembly is the highest representative body of the committee. ${ }^{22}$ Therefore, the highest levels in the field of technical regulation include the international and European levels. At these levels, the challenges are global in scope: removal of technical barriers in trade relations, facilitating the sharing of research and technological achievements, creation of a favorable environment for international economic cooperation. It should be understood that the objectives of the European technical regulation policy have a narrower focus on the achievement of domestic regulation objectives. ${ }^{23}$

As for the issues of regulation of standardization and certification in Ukraine, it should be mentioned that the legal and economic framework for standardization and certification systems, as well as their organizational forms in Ukraine, were determined in the 1993 Decree of the Cabinet of Ministers of Ukraine "On Standardization and Certification". ${ }^{24}$ Later, standardization regulation instruments in Ukraine were covered by the Law of Ukraine "On Standardization" adopted in 2001, which defines the legal and organizational framework for standardization and is designed to ensure a unified technical policy in this area. Then, in 2015, the new version of the Law of Ukraine "On Standardization" was presented in order to meet the EU requirements related to the signing of the EU-Ukraine Association Agreement.

As of January 1, 2016, Ukrainian national standards are gradually being replaced by relevant European standards, following the Association Agreement and the Order No. 1493 of the Ukrainian Ministry of Economic Development and Trade. The Agreement also refers to the abolition of GOST (CIS standards) in Ukraine. These changes initially raised concerns in the business

\footnotetext{
${ }^{21}$ Dupendant, J.: The Case of the International Organization for Standardization (ISO), 2016. [https://www.oecd.org/gov/regulatory-policy/ISO_Full-Report.pdf] accessed on 15/06/2021.

22 Gómez, V.Z.: A Soft Law, in: The Art of Legislating, Cham, 2019, p. 83-100.

23 Romanova, T.V., Voloshina, O.A., Gavrilenko, O.O.: Standardization of Ukrainian products when brought to the European market, 2015. [http://global-national.in.ua/archive/8-2015/127. pdf] accessed on 15/06/2021.

24 Gordienko, T.B.: Formation and optimization of the system of technical committees for standardization in Ukraine, Standards and Quality 7 2009, pp. 56-59.
} 
community that upgrading production facilities following the new rules would require additional capital expenditures, which can be excessive for some business owners, even despite the transition period. However, this did not provoke any significant opposition on the part of business owners. On the contrary, there came an understanding that this process is necessary in order to enter foreign markets and become competitive; therefore, businesses budgeted corresponding expenditures for the required procedures. ${ }^{25}$

As of January 1, 2019, most of the Soviet technical standards (GOST) developed before 1992 became invalid in Ukraine. Invalidation of Soviet GOST standards in Ukraine was sponsored by the Cabinet of Ministers and shaped by the government's 2015 action program. A total of 12,090 Soviet GOST standards were to be abolished. In order to reduce the risks for businesses, the Ministry of Economic Development and Trade asked stakeholders to submit their proposals for the abolition of standards that lost their relevance.

Throughout 2016-2018, the National Standards Body received proposals to extend the validity of some state standards. Upon requests from businesses, 1,173 standards were left in force until January 1, 2022. The standards that are expected to be replaced in the near future are still in force; relevant national standards instead of them are being developed or are expected to be developed soon; standards referenced in the regulations; standards of the Unified System for Design Documentation; standards which were developed based on the international standards, the current versions of which are relevant today. ${ }^{26}$

The EU-Ukraine Association Agreement provides for the establishment of a recognized national standards body, eligible to be a national member of the relevant international and regional standards bodies. Relevant foreign counterparts include ANSI (USA), DIN (Germany), BSI (UK), UNI (Italy), AFNOR (France), TSI (Turkey).

In its Resolution No. 1163-p dated November 26, 2014, the Cabinet of Ministers of Ukraine determined that the functions of the national standard bodies should be performed by the State Enterprise "Ukrainian Research and Training Center for Standardization, Certification and Quality Problems". The powers of the national standards bodies include, but are not limited to:

25 Garasim, Y.J.: Analysis of the national system of standardization and certification in the context of the Association Agreement between Ukraine and the EU, Foreign Trade: Economics, Finance, Law 3 2015, pp. 58-65.

26 The Ministry of Economic Development, Trade and Agriculture of Ukraine. From January 1, 2019, more than 90\% of Soviet GOSTs have expired in Ukraine, 2019. [https://www.me.gov. ua/News/Detail?lang=uk-UA\&id=29cb0e2f-d010-4264-9079-9709718a3123\&title=Z1-Sichni a2019-RokuBilshe90-RadianskikhGostivVtratiliChinnistVUkraini] accessed on 15/06/2021. 
- adoption and repeal of national standards (particularly in the field of construction, two years after the publication of the law).

- preparation and approval of the national standards action plan.

- establishment, termination of operations of Technical Committees for Standardization and coordination of their activities.

- representation of Ukraine in international and regional standards bodies.

- publication, reproduction, and dissemination of national standards.

- creation and operation of the national center for regulatory documents.

- compilation and maintenance of a directory of national standards. ${ }^{27}$

Today, the engineering industry is the main and, perhaps, the most sophisticated sector in Ukraine that requires adaptation to EU standards. Before 2014, the Ukrainian engineering industry focuses on CIS markets and partnered with suppliers through old ties established when the country was integrated into the Soviet production cycles, specialization arrangements, and factors of production. After the Russian aggression, the Russian market was closed to Ukrainian technological products. Expectations of a quick reorientation to the EU markets due to the establishment of the free trade area were not justified because of existing technical barriers. ACAA implementation could change the baseline conditions. ACAA provides for the harmonization of technical regulations, standards, and conformity assessment procedures of the member states with the EU legislation in certain areas, followed by mutual recognition of conformity assessments and test results. As of today, raw materials and semi-finished products are in a "privileged" position in the free trade area with the EU, while technical barriers have not been removed for technological manufactured goods. ${ }^{28}$

It should be noted that the Action Plan to prepare for ACAA signing was approved back in 2005. Over time, these intentions were covered in Article 57 of the EU-Ukraine Association Agreement. The documents confirm Ukraine's commitment to bring domestic legislation in line with European standards. The same applies to quality standards and the reform of the controlling bodies in this area. Tasks also include the abolition of several regulations that did not comply with European requirements, which, simultaneously with the prepara-

27 UkrNDNC: What does a National Standards body do? Q\&A, 2021. [http://uas.org.ua/ua/ pitannya-vidpovidi/] accessed on 15/06/2021.

28 Mirus, O.: When will there be "visa-free" in the EU for Ukrainian technological products, 2019. [https://www.epravda.com.ua/columns/2019/10/31/652964/] accessed on 15/06/2021. 
tion for ACAA signing, contributed to Ukraine's advancement in Doing Business global ranking. ${ }^{29}$

Once the ACAA is extended to the production sectors listed in its addenda, the parties, by mutual agreement and following the procedure for amending this Agreement, undertake to consider expanding their operations to other industries. The conclusion of the Agreement will open the Ukrainian and EU markets for manufactured goods based on mutual recognition of the results of conformity assessment of such products. The agreement is designed to become a unique format for cooperation and will include, inter alia, the following components:

- recognition of the equivalence of the requirements of Ukrainian technical regulations for products and the requirements of relevant EU directives.

- recognition of the equivalence of standards providing an assumption of conformity to the technical regulations and their lists, and the corresponding European harmonized standards and their lists.

- recognition of the equivalence of the requirements for designated bodies and those for notified bodies in the EU.

- Ukrainian manufacturers receive the right to affix "CE" - the European mark of conformity - to their products.

Low-voltage electrical equipment, electromagnetic compatibility of equipment, and machine safety were identified as priority sectors for the ACAA in the first phase. To ensure compliance with EU technical regulations, Ukraine should harmonize the systems of market surveillance, standardization, and conformity assessment bodies with the requirements of EU legislation. ${ }^{30}$

Adoption of the Law "On Amending Certain Legislative Acts of Ukraine to Reduce Pressure on Businesses by Market Surveillance Bodies", as required by the European Union to initiate the negotiations for the signing of ACAA, is one of the recent initiatives of the Ukrainian government to bring the country closer to signing the ACAA. With the adoption of this law, the last obstacle for Ukraine to begin negotiations on the fast-track (i.e., without additional certifi-

\footnotetext{
29 Obukh, V.: If Europe "automatically" recognizes the quality of Ukrainian industrial products, it will become more competitive in price, 2021. [https://www.ukrinform.ru/rubric-economy/2844897-v-2020m-ukraina-vrad-li-polucit-promyslennyj-bezviz-no-borotsa-nado.html] accessed on 15/06/2021.

30 Mission of Ukraine to the European Union, Access of Ukrainian goods to the EU market. ACAA Agreement, 2020. [https://ukraine-eu.mfa.gov.ua/en/2633-relations/torgovelno-ekonomichne-spivrobitnictvo-ukrayina-yes/dostup-ukrayinskih-tovariv-do-rinku-yes-ugoda-asaa] accessed on 15/06/2021.
} 
cations) export of manufactured goods to the EU has been removed. According to the report of the Presidential Administration, the law, among other things, is designed to reduce corruption risks during inspections by officials, as well as to strengthen consumer protection if dangerous non-food products are found on the market. The development and adoption of this legislative act are directly related to fulfilling the state's obligations under the Association Agreement with the European Union in terms of harmonization of Ukrainian market surveillance laws with EU legislation. The current version of the law provides for the elimination of duplication of control over certain types of products and unifies the types of inspections of non-food products (a legislative innovation designed to counter abuse); it establishes clear and transparent requirements for inspectors of market surveillance bodies and businesses concerning the list of documents and submission deadlines during inspections. ${ }^{31}$

As for the Agreement, its adoption is expected to facilitate the access of Ukrainian goods to the EU market, as well as to speed up and reduce the costs of certification procedures. In particular, the adoption of the Agreement should have a positive impact on small and medium-sized businesses, for which the costs of certification are the main obstacles on their way to EU markets.

\section{DISCUSSION}

The performance of companies in various sectors in the domestic and foreign markets depends on how the company products or services meet quality requirements. Proceeding from this condition, ensuring, and improving product quality is relevant for all countries and companies, and in many respects, the efficiency of the national economy depends on the solution of this issue. Standardization is directly related to quality management. The role of standardization in matters of improving product quality is reflected, as a rule, in the integrated development of standards for raw materials and components, as well as the establishment of the standards of technological requirements and quality indicators, unified test methods, and controls. ${ }^{32}$ The fact that only by making products, that meet European quality and safety standards, domestic companies may expect increased exports to the EU, and also to many other countries, has long been accepted by large Ukrainian businesses that have largely man-

\footnotetext{
31 Official website of President Of Ukraine, The President signed a law to reduce pressure on business from market surveillance authorities, 2019. [https://president.gov.ua/news/prezident-pidpisav-zakon-shodo-zmenshennya-tisku-na-biznes-z-59045/?fbclid=IwAR05e6In4o1TM5URomZITzMRD-kUIvUyI3vM_12qHVArcqeILhbw5vFdkSs] accessed on 15/06/2021.

32 Melnyk, T.M., Pugachevska, K.S.: Non-tariff Protectionism in EU Countries and Ukraine, Business Inform 1 2014, pp. 20-27.
} 
aged to adapt to the conditions and requirements of Western markets, not to mention the services of various financial consultants and special consulting firms offered to large businesses.

Medium-sized businesses - seen as the most vulnerable in Ukraine - often lack financial resources, persistence in overcoming bureaucracy, and assistance in conducting due diligence. Small businesses found themselves in an even harder situation, and the most successful ones manage to break into the EU market solely due to their innovativeness.

Unfortunately, there is no program on the part of the government to educate and encourage the transition to European standards in many areas. After overcoming the safety requirements, Ukrainian products will face another obstacle on their way to the EU markets - private standards created by large chains or sector-based business associations. Such quality and safety standards are above the minimum standards, but in essence, they are the instruments of hidden protectionism, veiled by slogans of consumer protection, and targeting primarily newcomers from outside the EU. ${ }^{33}$

The issue of non-tariff barriers as disguised protection of domestic manufacturers has often been mentioned in recent studies. ${ }^{34}$ Such barriers include product standards, health and safety regulations, and labeling requirements. Many services have licensing requirements and restrictions on those who are eligible to obtain permits. These kinds of barriers often have good reasons - such as consumer protection. However, it should be mentioned that, as instruments of influence on trade, they can be a form of disguised protection for national suppliers. ${ }^{35}$ The possibility of protectionist measures applied by the European Union was considered long before Ukraine signed the Association Agreement, and it did not come as a surprise to Ukraine. ${ }^{36}$

Against the backdrop of the current crisis in the global economy, the adverse situation on global commodity markets has had an adverse impact on the

33 Bollen, Y., De Ville, F., Orbie, J. : EU trade policy: Persistent liberalisation, contentious protectionism, Journal of European Integration, 38(3) 2016, pp. 279-294. [doi:10.1080/070363 37.2016.1140758]

34 Emerson, M., Kofner, J.: Technical product standards and regulations in the EU and EAEU-comparisons and scope for convergence. IIASA Report, Laxenburg, Austria, 2018; Cipollina, M., Demaria, F.: The trade effect of the EU's preference margins and non-tariff barriers, Journal of Risk and Financial Management, 13(9) 2020, p. 203.

35 Walker, A.: Is the European Union a 'protectionist racket'?, 2018. [https://www.bbc.com/ news/business-44291103] accessed on 15/06/2021.

36 Melnyk, T.M., Pugachevska, K.S.: Non-tariff Protectionism in EU Countries and Ukraine, Business Inform, 1 2014, pp. 20-27. 
Ukrainian economy as well. Under these conditions, economic recovery will require huge public expenditures. However, given the fact that the Ukrainian government is unlikely to be able to allocate sufficient funds on its own, the EU could potentially play a crucial role here. The issue of applying a kind of Marshall Plan for Ukraine has been repeatedly raised in recent studies. ${ }^{37}$

Given the events taking place in Ukraine over the last 5 years, the sanctions policy of the West against Russia related to these events, and given the fact that the provision of economic assistance to Ukraine has been a quite regular item on the global foreign policy agenda, at a certain phase after the signing of the Association Agreement, there was a perception in political circles that Ukraine might need a combination of protectionism and an external strategy to overcome the adverse effects on its economy. However, the state's obligations to its foreign partners, implying the need to keep Ukraine's economy open, were the main obstacle to the introduction of such steps. Long and difficult negotiations might be needed to convince international organizations, primarily the WTO and the EU, that those special circumstances, a combination of many intrinsic factors that have caused the economic downturn in the country, require outof-the-box, exceptional measures. The goodwill of international organizations will help to make an asymmetric decision and ensure its implementation. ${ }^{38}$

Strengthening the national market in this environment would be a significant factor that could affect the adverse trends in the Ukrainian economy. Protectionist measures in this case should be seen as temporary and of an exceptional nature, designed for political support for Ukraine. ${ }^{39}$ At the moment, there is no need to speak about any significant expansion of Ukrainian goods to the European market.

However, as can be seen from the dispute between Ukraine and the EU arising from the 2015 moratorium on the export of unprocessed timber, at the moment, the EU proceeds primarily from its priorities, and it would be rash to talk about such exceptional concessions for Ukrainian businesses on the part of the EU. Although the Arbitration Panel, established to resolve this dispute, eventually admitted the fact that Ukraine can and has the right to restrict timber exports, and the existing export ban of 2005 was found to be fully legitimate,

37 Miskimmon, A., O'Loughlin, B.: An EU recovery programme for Ukraine? Towards a new narrative for EU-Ukraine relations?. Cognition, Communication, Discourse, 172018 , pp. 75-91. [https://doi.org/10.26565/2218-2926-2018-17-05]; Daehnhardt, P.: German foreign policy, the Ukraine crisis and the Euro-Atlantic order: Assessing the dynamics of change, German Politics, 27(4) 2018, pp. 516-538. [https://doi.org/10.1080/09644008.2018.1448386]

38 Oleinik, A.: Open economy or protectionism: Ukraine's dilemma, Montenegrin Journal of Economics, 14(3) 2018, pp. 109-127.

39 Ibid. 
the EU takes the view that this ban contradicts Article 35 of the Association Agreement ("Export and Import Restrictions"). This is the first-ever dispute within the framework of the EU-Ukraine Association Agreement. ${ }^{40}$

As to the fast-track arrangements for exporting manufactured goods to the EU, and the hopes that Ukrainian businesses have for it, one should not forget that ACAA works both ways: according to the agreement, Ukraine should facilitate the access of European products to its market. Taking into consideration the fact that Ukrainians prefer foreign products, and that domestic banks and non-banking financial institutions provide consumer loans for the purchase of imports (which, indeed, adversely affects the country's foreign trade balance), the fast-track arrangements are quite capable of adding problems to the Ukrainian economy. It is possible that during the first phases of the introduction of the fast-track export arrangements, Ukraine may receive an adverse economic effect. This is due to the fact that, unlike Ukrainian raw materials, components, and semi-finished products, which have already gained credibility in the European market, manufacturers, and suppliers of Ukrainian manufactured goods have yet to learn the path to the EU markets.

However, it should be mentioned that this circumstance is not without its upsides. In particular, in a competitive environment, it will improve the quality of Ukrainian manufactured goods - both exported and for the domestic market. Based on this understanding, Ukraine will ultimately benefit from the introduction of fast-track export arrangements. ${ }^{41}$

Speaking about the current situation in Ukraine with the regulation of standardization and certification, it should be understood that the transition to a new model in this area is a long and gradual process. Because of this, difficulties arise during the transition period. Certain categories of goods have no standards that would be a criterion for their safety or quality. This has happened because many of the GOST standards (that were in force earlier) have already been abolished, and the relevant technical regulations have not yet been implemented. Bona fide manufacturers or importers would benefit

\footnotetext{
40 Integrated Executive Summary of the European Union Integrated executive summary of the European Union. To the arbitration panel established pursuant to article 306 of the Association Agreement between the European Union and the European Atomic Energy and their Member States and Ukraine in the dispute Ukraine - Export prohibitions on wood products, 2020. [https://trade.ec.europa.eu/doclib/docs/2020/october/tradoc_158969.pdf] accessed on $15 / 06 / 2021$

41 Obukh, V.: If Europe "automatically" recognizes the quality of Ukrainian industrial products, it will become more competitive in price, 2021. [https://www.ukrinform.ru/rubric-economy/2844897-v-2020m-ukraina-vrad-li-polucit-promyslennyj-bezviz-no-borotsa-nado.html] accessed on 15/06/2021.
} 
from the absence of additional regulatory formalities. However, at the same time, this situation creates room for abuse. ${ }^{42}$ The new certification format has reduced the bureaucratic pressure on manufacturers, but, along with simplifications for businesses, it has weakened control over product quality and safety. Compliance with standards is now a matter of the manufacturers or importer's integrity and reputation.

\section{CONCLUSIONS}

In general, one could quite positively assess the aspirations of Ukraine on the way to adapting to the European regulation of standardization and certification. However, until now policy makers' efforts to adopt legislation in the relevant area have not yet been crystallized in the expected results at the macroeconomic and sectoral levels. Despite numerous shocks in the political and economic aspects of the country's life (transition to the market economy, failed privatization, the aftermath of the Global Economic Crisis), the state has been able to maintain (and even strengthen) its research and technological capabilities. However, it would be wrong to say that in foreign trade the country is able to supply foreign customers solely with industrial goods such as raw materials, semi-finished products, etc.

Speaking about the entry of Ukrainian manufactured goods into the European market, there is a probability of protectionist measures in the form of non-tariff barriers. One cannot rule out the possibility that the Ukrainian government and regulators, prompted by the initiatives of private companies, may resort to similar measures. However, the likelihood of such an outcome is currently seen as very low due to the common political views and approaches regarding trade relations between Ukraine and the EU.

Adaptation of Ukrainian legislation to European certification criteria contributed to the reduction of bureaucratic pressure on manufacturers, but at the same time created preconditions for a weaker control over the product quality and safety. The way the new certification arrangements will affect product quality, business environment, and trade relations between Ukraine and the EU should be the focus of future studies.

42 Rodichkina, A.: Divorce with GOST: how Ukraine is implementing a new model of standardization, 2020. [https://www.epravda.com.ua/projects/regulation/5faa7f53e88e6/] accessed on $15 / 06 / 2021$. 


\section{LITERATURE}

1. Bollen, Y., De Ville, F., Orbie, J. : EU trade policy: Persistent liberalisation, contentious protectionism, Journal of European Integration, 38(3) 2016, pp. 279-294. - DOI: doi:10.1080/07036337.2016.1140758

2. Cormenier, T., Patra, M., Garnier, C.: European CEN-CENELEC standardization on material efficiency for longer lifespan within circular economy, ELTEE 2018 2018, pp. 1-10.

- DOI: https://doi.org/10.29007/ttxl

3. Curzi, D., Luarasi, M., Raimondi, V., Olper, A. : The (lack of) international harmonization of EU standards: import and export effects in developed versus developing countries, Applied Economics Letters, 25(21) 2018, pp. 1552-1556.

- DOI: https://doi.org/10.1080/13504851.2018.1430327

4. Daehnhardt, P.: German foreign policy, the Ukraine crisis and the Euro-Atlantic order: Assessing the dynamics of change, German Politics 27(4) 2018, pp. 516-538. - DOI: https://doi.org/10.1080/09644008.2018.1448386

5. Dupendant, J.: The Case of the International Organization for Standardization (ISO), 2016. [https://www.oecd.org/gov/regulatory-policy/ISO_Full-Report.pdf] accessed on 15/06/2021.

6. Emerson, M., Kofner, J.: Technical product standards and regulations in the EU and EAEU-comparisons and scope for convergence. IIASA Report, Laxenburg, Austria, 2018.

7. Cipollina, M., Demaria, F.: The trade effect of the EU's preference margins and non-tariff barriers, Journal of Risk and Financial Management, 13(9) 2020, p. 203. - DOI: https://doi.org/10.3390/jrfm13090203

8. Eurointegration portal: 'An effective standardization system is high-quality and safe products', 2018. [http://eu-ua.org/analityka/efektyvna-systema-standartyzaciyi-yakisna-ta-bezpechna-produkciya] accessed on 15/06/2021.

9. Garasim, Y.J.: Analysis of the national system of standardization and certification in the context of the Association Agreement between Ukraine and the EU, Foreign Trade: Economics, Finance, Law, 3 2015, pp. 58-65.

10. Gómez, V.Z.: A Soft Law, in: The Art of Legislating, Cham, 2019, p. 83-100. - DOI: https://doi.org/10.1007/978-3-030-23388-4_6

11. Gordienko, T.B.: Formation and optimization of the system of technical committees for standardization in Ukraine, Standards and Quality 7 2009, pp. 56-59.

12. Integrated Executive Summary of the European Union Integrated executive summary of the European Union. To the arbitration panel established pursuant to article 306 of the Association Agreement between the European Union and the European Atomic Energy and their Member States and Ukraine in the dispute 
Ukraine - Export prohibitions on wood products, 2020. [https://trade.ec.europa. eu/doclib/docs/2020/october/tradoc_158969.pdf] accessed on 15/06/2021.

13. Melnyk, T.M., Pugachevska, K.S.: Non-tariff Protectionism in EU Countries and Ukraine, Business Inform, 1 2014, pp. 20-27.

14. Mirus, O.: "When will there be "visa-free" in the EU for Ukrainian technological products', 2019. [https://www.epravda.com.ua/columns/2019/10/31/652964/] accessed on 15/06/2021.

15. Miskimmon, A., O'Loughlin, B.: An EU recovery programme for Ukraine? Towards a new narrative for EU-Ukraine relations?, Cognition, Communication, Discourse, 17 2018, pp. 75-91.

- DOI: https://doi.org/10.26565/2218-2926-2018-17-05

16. Mission of Ukraine to the European Union, Access of Ukrainian goods to the EU market. ACAA Agreement, 2020. [https://ukraine-eu.mfa.gov.ua/en/2633-relations/torgovelno-ekonomichne-spivrobitnictvo-ukrayina-yes/dostup-ukrayinskih-tovariv-do-rinku-yes-ugoda-asaa] accessed on 15/06/2021.

17. Obukh, V.: If Europe "automatically" recognizes the quality of Ukrainian industrial products, it will become more competitive in price, 2021. [https://www. ukrinform.ru/rubric-economy/2844897-v-2020m-ukraina-vrad-li-polucit-promyslennyj-bezviz-no-borotsa-nado.html] accessed on 15/06/2021.

18. Official website of President Of Ukraine, The President signed a law to reduce pressure on business from market surveillance authorities, 2019. [https://president.gov.ua/news/prezident-pidpisav-zakon-shodo-zmenshennya-tisku-na-biznes-z-59045/?fbclid=IwAR05e6In4o1TM5URomZITzMRD-kUIvUyI3vM_ 12qHVArcqeILhbw5vFdkSs] accessed on 15/06/2021.

19. Oleinik, A.: Open economy or protectionism: Ukraine's dilemma, Montenegrin Journal of Economics, 14(3) 2018, pp. 109-127.

- DOI: https://doi.org/10.14254/1800-5845/2018.14-3.8

20. Predmestnikov, O., Gumenyuk, V.: Harmonization of economic and legal mechanisms for deepening EU-Ukrainian relations, Baltic Journal of Economic Studies, 5(1) 2019, pp. 174-181.

- DOI: https://doi.org/10.30525/2256-0742/2019-5-1-174-181

21. Rodichkina, A.: Divorce with GOST: how Ukraine is implementing a new model of standardization, 2020. [https://www.epravda.com.ua/projects/regulation/5faa7f53e88e6/] accessed on 15/06/2021.

22. Romanova, T.V., Voloshina, O.A., Gavrilenko, O.O.: Standardization of Ukrainian products when brought to the European market, 2015. [http://global-national.in.ua/archive/8-2015/127.pdf] accessed on 15/06/2021.

23. Schepel, H., Falke, J.: Legal aspects of standardisation in the Member States of the EC and EFTA (Vol. 1), Office for official publications of the European communities, 2000. 
24. The Ministry of Economic Development, Trade and Agriculture of Ukraine. From January 1, 2019, more than 90\% of Soviet GOSTs have expired in Ukraine, 2019. [https://www.me.gov.ua/News/Detail?lang=uk-UA\&id=29cb0e2f-d010-42 64-9079-9709718a3123\&title=Z1-Sichnia2019-RokuBilshe90-RadianskikhGostivVtratiliChinnistVUkraini] accessed on 15/06/2021.

25. UkrNDNC: What does a National Standards body do? Q\&A, 2021. [http://uas. org.ua/ua/pitannya-vidpovidi/] accessed on 15/06/2021.

26. Van der Loo, G.: The EU-Ukraine Association Agreement and Deep and Comprehensive Free Trade Area: a new legal instrument for EU integration without membership, Brill, 2016.

- DOI: https://doi.org/10.1163/9789004298651

27. Walker, A.: Is the European Union a 'protectionist racket'?, 2018. [https://www. bbc.com/news/business-44291103] accessed on 15/06/2021.

28. Wolczuk, K., Žeruolis, D.: Rebuilding Ukraine: An assessment of EU assistance, Ukraine Forum, 402018.

29. WTO: 'Trade policy review - Report by the Secretariat - Ukraine', 2016. [https:// www.wto.org/english/tratop_e/tpr_e/s334_e.pdf] accessed on 15/06/2021. 